УДК 656.022

\title{
СУЧАСНИЙ СВІТОВИЙ ДОСВІД РОЗВИТКУ ВИСОКОШВИДКІСНОГО РУХУ ПАСАЖИРСЬКИХ ПОЇЗДІВ ТА ДОСЛІДЖЕННЯ ПЕРСПЕКТИВ ЙОГО РОЗВИТКУ В УКРАÏHI
}

Д-р техн. наук О.В. Лаврухін, кандидати техн. наук Д.І. Мкртичьян, О.М. Костєнніков, магістрант А.Д. Іващенко

\section{СОВРЕМЕННЫЙ МИРОВОЙ ОПЫТ РАЗВИТИЯ ВЫСОКОСКОРОСНОГО ДВИЖЕНИЯ ПАССАЖИРСКИХ ПОЕЗДОВ И ИССЛЕДОВАНИЕ ПЕРСПЕКТИВ ЕГО РАЗВИТИЯ В УКРАИНЕ}

Д-р техн. наук А.В. Лаврухин, кандидаты техн. наук Д.И. Мкртычян, А.М. Костенников, магистрант А.Д. Иващенко

\section{CURRENT WORLD EXPERIENCE OF HIGHT-SPEED PASSENGER TRAINS AND RESEARCH PERSPECTIVES OF ITS DEVELOPMENT IN UKRAINE}

Dr. of techn. sciences O.V. Lavruhin, Ph.D D.I. Mkrtychyan, Ph.D O.M. Kostennikov, master student A.D. Ivashchenko

Сучасні тенденції на ринку транспортних послуг з перевезення пасажирів полягають у відносному зменшенні ролі залізничного й підвищенні значення автомобільного й повітряного транспорту. У зв'язку з иим виникає необхідність проведення державних заходів стосовно посилення привабливості саме залізничних перевезень для населення за рахунок упровадження швидкісних магістралей.

Ключові слова: залізничний транспорт, пасажирські перевезення, високошвидкісні магістралі, інфраструктура.

Современные тенденции на рынке транспортных услуг по перевозке пассажиров заключаются в относительном уменьшении роли железнодорожного и повышении значения автомобильного $u$ воздушного транспорта. В связи с этим возникает необходимость проведения государственных мероприятий по усилению привлекательности именно железнодорожных перевозок для населения за счет внедрения скоростных магистралей.

Ключевые слова: железнодорожный транспорт, пассажсирские перевозки, высокоскоростные магистрали, инфраструктура.

The world experience of the implementation of the high-speed railway traffic by rail of Western Europe and Japan, Great Britain, France, Germany, Belgium, Holland, Spain, Italy, France and China is considered. Considering the international experience we can conclude that the development of high-speed transport in Ukraine should be based on already known success and broad interest to high-speed traffic on the part of politicians and society. Future network development is increasingly linked with international transport for which European countries are developing special marketing concept in order to gain a foothold in the market. A necessary condition for solving this problem in Ukraine is the fastest completion of infrastructure development provided the participation of all stakeholders and attract investors and creditors. This way makes it possible to preserve the railway industry and the most efficient use of existing scientific and technical potential for structural and technological changes to conserve competitive advantage over other modes of transport.

Key words: rail, passenger transport, high-speed highway, infrastructure.

Вступ i постановка проблеми у загальному вигляді та їі зв'язок із важливими науковими та практичними завданнями. Інтеграційні процеси у світі та участь в них України спричиняють подальший розвиток єдиного європейського ринку товарів і послуг узагалі і транспортного ринку зокрема, що служить важливою основою зростання 
обсягів не тільки вантажних, а й пасажирських перевезень. У таких умовах висуваються принципово нові вимоги до якості транспортного обслуговування, що пов'язано в першу чергу із підвищенням швидкості доставки пасажирів. Майбутнє пасажирських перевезень на залізничному транспорті України пов'язане 3 реалізацією стратегічних рішень, серед яких реформування галузі та впровадження великомасштабних інноваційних проектів залежить від подальшого розвитку і вдосконалення швидкісних магістралей, a надалі - створення високошвидкісних магістралей.

Україна має високорозвинену мережу залізниць. 3 iї загальної експлуатаційної протяжності (22,05 тис. км) 67,5\% становлять одноколійні ділянки, 32,5 - дво- і триколійні. Електрифіковано 42,3 \% протяжності залізниць, 60,7 - обладнано пристроями автоматичного регулювання руху поїздів, 62 - мають безстикову колію, системами електричної централізації обладнано $72,9 \%$ всіх стрілок. Велика провізна спроможність залізниць, стабільність їх роботи та порівняна дешевина перевезень сприяли тому, що залізничний транспорт був і залишається у країні основним перевізником пасажирів у міжміському (далекому) та приміському сполученні [5].

Згідно зі звітом про глобальну конкурентоспроможність (The Global Competitiveness Report 2013-2014), за критерієм оцінки залізничної інфраструктури наша країна займає 25-те місце у світі [1]. Але хронічна нестача грошей на модернізацію 3 кожним роком робить вітчизняні залізничні перевезення все менш конкурентоспроможними. Значно підвищити конкурентоспроможність залізничного транспорту можна, впроваджуючи та розвиваючи так званий пришвидшений рух (до 160 км/год) на основі наявних шляхів.

Визначення мети та задачі дослідження. Основною метою статті є аналіз розвитку швидкісних пасажирських перевезень у світі та їх стан упровадження в Україні.

\section{Аналіз останніх досліджень.}

Проблемами розвитку високошвидкісних пасажирських перевезень в Україні займалися фахівці Укрзалізниці та вчені Г.М. Кірпа, В.Л. Дикань, Т.В. Бутько, А.В. Момот та ін. $[3,4,6]$.

Основна частина дослідження. Через жорстку конкуренцію 3 боку інших видів транспорту (особливо авіаційного) радикальним i ефективним заходом у підвищенні швидкостей перевезень пасажирів у внутрішньому та міжнародному сполученнях $\epsilon$ створення мережі швидкісних залізничних магістралей (МШЗМ) із з'єднанням 3 європейськими залізницями і залізницями країн СНД. Вони призначаються для вирішення комплексу соціальних, економічних i екологічних проблем. Завдяки збільшенню швидкостей руху до 160-200 км/год і більше, а також більшої точності, надійності i комфортності поїздок підвищується конкурентоспроможність у ринкових умовах залізничного транспорту. Він стає основним засобом перевезень людей територією України та із сусідніми державами.

Європейські та міжнародні стандарти визначають, що швидкісний рух - це такий рух, який забезпечує поїздки між двома пунктами зі швидкостями в інтервалах 141-160 і 161200 км/год. Українські відомчі нормативи представляють швидкісний рух пасажирських поїздів як рух пасажирських поїздів із швидкостями в інтервалах [9]:

- 141-160 км/год - пришвидшений рух;

- 161-200 км/год - швидкісний рух;

- понад 200 км/год - високошвидкісний pyx.

Досвід країн Західної Європи та Японії показує, що найбільшої швидкості руху - 200350 км/год можна досягти, організовуючи високошвидкісний рух поїздів на спеціалізованих високошвидкісних магістралях. Проте їх будівництво i виробництво спеціалізованого рухомого складу потребує великих капіталовкладень, бо їм має передувати будівництво окремих швидкісних магістралей.

Зміцнення конкретних позицій авіаційного та автомобільного транспорту на ринку транспортних послуг на початку 80-х років XX сторіччя в державах Західної Свропи призвели до зменшення обсягів вантажних i пасажирських перевезень. Тому постало питання, яким чином зміцнювати конкурентні позиції залізниць на транспортному ринку. Ефективним заходом стало створення на підставі досвіду Японії високошвидкісної мережі залізниць (ВШМЗ). Уперше в Європі було збудовано у 1981 році швидкісну лінію Париж - Ліон. Європейські держави стали співпрацювати по створенню ВШМЗ. 
Результатом такої співпраці стала підготовка у 1985 р. концепції створення ВШМЗ, а у 1989 р. європейська нарада міністрів розглянула „Пропозиції щодо європейської високошвидкісної мережі”. Після цього державами розпочато реалізацію названих пропозицій.

Мережі швидкісних сполучень різних країн поступово інтегруються, утворюючи єдину європейську мережу. Вона має такі ланки:

- сполучення Eurostar - за допомогою цих сполучень Великобританія отримала постійний “сухопутний” зв'язок залізниці 3 країнами континентальної Європи через тунель під Ла-Маншем;

- сполучення Thalys - ці сполучення пов'язують великі міста чотирьох країн: Париж, Лілль (Франція), Брюссель, Антверпен, Льєж (Бельгія), Амстердам, Гаагу, Роттердам (Нідерланди), Ахен, Кельн, Дюссельдорф (Німеччина);

- сполучення Rbealys - високошвидкісний напрямок 3 Парижа у Страсбург, Люксембург та інші великі німецькі міста.

На відстанях між 500 і 1000 км існує інтенсивна конкуренція між залізничним та повітряним транспортом, і вирішальну роль при виборі пасажирами виду транспорту меншою мірою відіграють тривалість поїздки або польоту, а більшою - набір і якість послуг, що надаються, а також можливість адаптації до постійно змінюваних умов перевезень.

Найбільш розвинутими ВШМЗ в Японії, Франції, Німеччині, Італії й Іспанії, у кожній $з$ яких такі системи розвивались своїм шляхом 3 урахуванням характерних їм особливостей. Незважаючи на суттєві відмінності в розвитку ВШМЗ ці держави можна поділити на три групи за характерними однаковими ознаками розвитку систем:

- в Японії й Іспанії система ВШМЗ повністю ізольована від іншої мережі залізниць;

- у Франції будуються нові ВШМЗ у складі загальної мережі залізниць;

- у Німеччині й Італії здійснюється комплексна реконструкція залізничних напрямків, яка передбачає будівництво високошвидкісних дільниць у поєднанні 3 модернізацією і спрямленням існуючих ліній для організації високошвидкісного руху.
Будівництво нових ВШМЗ (досвід Японії й Іспанії) потребує значних капітальних вкладень. Через значну обмеженість фінансових ресурсів i наявність високорозвиненої i незавантаженої мережі залізниць, найбільш доцільно скористуватись досвідом Німеччини й Італії з модернізації $\mathrm{i}$ спрямлення існуючих магістралей для реалізації швидкісного руху. ВШМЗ в державах Західної Європи стала серйозним конкурентом для авіатранспорту, а в деяких випадках особистих легкових автомобілів. Значна частина загального обсягу пасажирських перевезень (до 90\%) при відстанях поїздок менше 500 км, при їх тривалостях до 2,5 год виконується ВШМЗ. При відстанях перевезень більше 1000 км відбувається конкуренція між залізницями та авіатранспортом. Переможцем у цій боротьбі за першість на транспортному ринку вийде той вид транспорту, який надасть пасажирам більш широкий сервісний спектр послуг вищої якості.

У західних державах паралельно створенню високошвидкісних магістралей (ВШМ) проводиться робота 3 підвищення швидкості пасажирського руху на лініях, де здійснюється разом рух вантажних i пасажирських поїздів. Як свідчить досвід залізниць таких держав, на лініях із суміщеним рухом вантажних i пасажирських поїздів швидкість руху пасажирських поїздів через значні відмінності технічних параметрів для різних видів руху має обмеження. Вона, як правило, не перевищує 200-220 км/год. Схема мережі транс'європейських високошвидкісних залізниць довжиною 12600 км, затверджена Європейською радою,буде введена в експлуатацію у 2010 році.

Із західноєвропейського досвіду видно, що, незважаючи на наявність добре розвинутої мережі автомобільних доріг, широке охоплення населення власними автомобілями, залізничний транспорт при проведенні відповідної роботи має переваги перед автомобільним транспортом (на відстанях 250-500 км), а також успішно конкурує з авіацією (на відстанях 5001000 км).

До впровадження швидкісного руху пасажирських поїздів в Україні підготовка тривала не один рік. Відповідно до Транспортної стратегії України на період до 2020 року та Концепції впровадження швидкісного руху пасажирських поїздів на 
залізницях України у 2004-2015 роках [3,5] до Євро-2012 було впроваджено швидкісний рух на окремих напрямках між містами-учасниками футбольних змагань. Для цього впроваджено цілий комплекс необхідних заходів: від розроблення потрібної документації, прийняття державних програм до підготовки залізничної інфраструктури, закупівлі та випробування нової техніки та навчання персоналу.

Усе це привело до створення Державного підприємства «Українська залізнична швидкісна компанія», яке є новим потужним гравцем на ринку пасажирських перевезень України та першопроходцем у напрямку розвитку абсолютно нового сегмента пасажирських перевезень - денних швидкісних перевезень.

Основною діяльністю ДП «Українська залізнична швидкісна компанія» $\epsilon$ швидкісні пасажирські залізничні перевезення. На сьогоднішній день парк рухомого складу компанії складається $3 \quad 10$ електропоїздів категорії IHTEPCITI+ виробництва «Hyundai Rotem» та iз 2 електропоїздів категорії IHTEPCITI виробництва компанії «Skoda». Компанія має основні технічні бази 3 обслуговування рухомого складу в Києві (станція Дарниця) та Харкові [8]. Таким чином, проблеми впровадження швидкісного пасажирського руху та прискорення існуючого лежать як у площині техніко-технологічних, так i важливих організаційно-економічних завдань, тільки комплексний підхід на базі системи науково обгрунтованих принципів та подальших управлінських рішень забезпечить їх ефективне вирішення.

Сучасні тенденції на ринку транспортних послуг 3 перевезення пасажирів полягають у відносному зменшенні ролі залізничного й підвищенні значення автомобільного й повітряного транспорту. Виходячи 3 аналізу обсягів перевезення пасажирів за трьома видами транспорту [7] (рисунок) можна зробити висновок, що від $4 \%$ до $5 \%$ населення України будуть i надалі користуватися авіатранспортом, а збільшення обсягів швидкісних залізничних перевезень можливе за рахунок переорієнтації користувачів 3 автомобільного транспорту, але за умови підвищення платоспроможності населення та будівництва швидкісних та високошвидкісних залізничних магістралей.

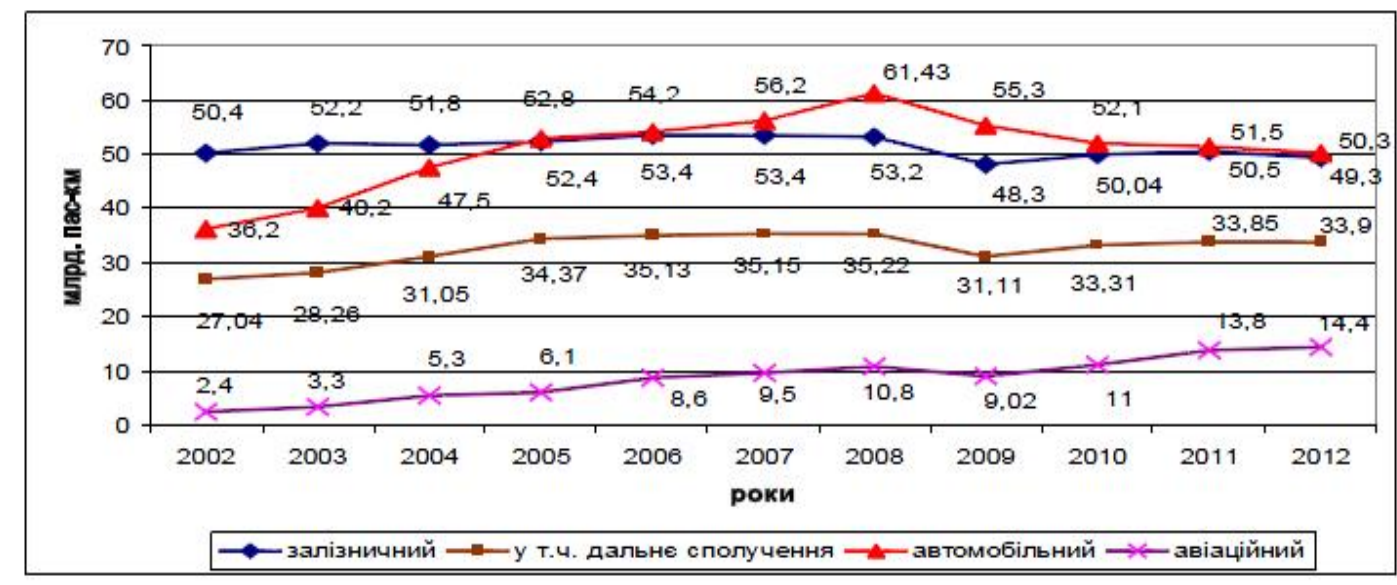

Рис. Динаміка пасажирообороту за трьома видами транспорту

Висновки 3 дослідження і перспективи, подальший розвиток у даному напрямку. Розглядаючи світовий досвід можна зробити висновок, що розвиток високошвидкісних перевезень в Україні повинен базуватися на вже відомих успіхах, а також 3 широкою зацікавленістю до високошвидкісних перевезень зі сторони політиків та суспільства. Майбутній розвиток мережі значною мірою буде пов'язано з міжнародними перевезеннями, для яких країни Європи розробляють спеціальні концепції маркетингу 3 метою закріпитися на ринку. Необхідною умовою вирішення даної задачі в Україні є максимально швидке завершення робіт 3 розвитку інфраструктури за умови участі всіх зацікавлених сторін та залучення інвесторів та кредиторів. Саме такий шлях дає можливість 


\section{Експлуатація залізниць}

галузі залізничного транспорту зберегти й найбільш ефективно використовувати існуючий науково-технічний потенціал для здійснення структурних технологічних змін та для збереження конкурентних переваг перед іншими видами транспорту.

\section{Список використаних джерел}

1. Аналіз індексу конкурентоспроможності України в 2013-2014 pp. [Електронний ресурс]. Режим доступу: http://infolight.org.ua/content/analiz-indeksu-konkurentospromozhnosti-ukrayini-v-20132014-rr.

2. Формування моделі розвитку залізничної системи швидкісних перевезень на основі принципів самоорганізації [Текст] / Т.В. Бутько, А.В. Прохорченко, Л.О. Пархоменко [та ін.] // Вісник Національного технічного університету "ХПІ": зб. наук. праць. Тематичний випуск: Нові рішення в сучасних технологіях. - Харків: НТУ „ХПІ”, 2011. - № 54. - С. 67-70.

3. Дикань, В.Л. Скоростное движение железнодорожного транспорта в мире и перспективы его развития в Украине [Текст] / В.Л. Дикань, И.В. Корнилова // Вісник економіки транспорту та промисловості. - 2010. - № 32. - С. 15-25.

4. Кірпа, Г.М. Інтеграція залізничного транспорту України в Європейську транспортну систему [Текст]: монографія / Георгій Кірпа. - Дніпропетровськ: ДНУЗТ, 2004. - 248 с.

5. Концепція Державної цільової програми впровадження на залізницях швидкісного руху пасажирських поїздів на 2005-2015 роки [Електронний ресурс]: Розпорядження Кабінету Міністрів України від 31 грудня 2004 р. № 979-p. - Режим доступу: http://zakon2.rada.gov.ua/laws/ show/9792004-p

6. Момот, А.В. Методичний підхід до визначення раціональних швидкостей руху пасажирських поїздів та раціональних зон їх курсування [Текст] / А.В. Момот // Проблеми економіки транспорту: зб. наук. праць. Дніпропетр. нац. ун-ту заліз. трансп. ім. акад. В. Лазаряна. Дніпропетровськ: Вид-во Дніпропетр. нац. ун-ту залізн. трансп. ім. акад. В. Лазаряна, 2013. - Вип. 5. - С. 80-89.

7. Офіційний сайт Державної служби статистики України [Електронний ресурс]. - Режим доступу: www.ukrstat.gov.ua.

8. Офіційний сайт Укрзалізниці [Електронний ресурс]. - Режим доступу: http://uz.gov.ua.

9. Тимчасова інструкція з організації швидкісного руху пасажирських поїздів. Вимоги до інфраструктури та рухомого складу [Текст]: ВНД 32.1.07.000-02. Укрзалізниця. - К., 2002. - 51 с.

10. Транспортна стратегія України на період до 2020 року [Електронний ресурс]: Розпорядження Кабінету Міністрів України від 20.10.2010 p. № 2174-р. - Режим доступу: http://zakon2.rada.gov.ua/laws/show/2174-2010-p.

Лаврухін Олександр Валерійович, д-р техн. наук, доцент кафедри управління вантажною і комерційною роботою. Тел.: 057-730-10-85.

Мкртичьян Дмитро Ігорович, канд. техн. наук, доцент кафедри управління вантажною і комерційною роботою. Тел.: 057-730-10-11.

Костєнніков Олексій Михайлович, канд. техн. наук, доцент кафедри управління вантажною і комерційною роботою. Тел.: 057-730-19-89, e-mail: alexeykostennikov@yandex.ru.

Іващенко Альона Дмитріївна, слухач групи МЗ-ОПУТ-14-Т.

Olexander Valerievich Lavruhin, Dr., professor of the chair "Management of freight and commercial operation". Tel.:057-730-10-85.

Dmitry Igorovich Mkrtychyan, $\mathrm{Ph}$. D, associate professor of the chair "Management of freight and commercial operation". Tel.: 057-730-10-11.

Kostennikov Olexiy Mikhaylovich, Ph. D, associate professor of the chair "Management of freight and commercial operation". Tel.:057-19-89, e-mail: alexeykostennikov@yandex.ru.

Ivashchenko Alena Dmitrievna, student of the group M3-ROM-14-T.

Наукова праця здана до друку 15.07.2015 року 